\title{
25 Research Suare \\ Gastrointestinal Helminth Parasites of Wild Ungulates In Hirpora Wildlife Sanctuary, Kashmir, India
}

\author{
Rouf Ahmad Bhat \\ University of Kashmir \\ Hidayatullah Tak \\ University of Kashmir \\ Bilal A. Bhat \\ University of Kashmir \\ Riyaz Ahmad \\ Wildlife Trust of India \\ Jahangir Ahmad Dar ( $\square$ jahangirwildlife10@gmail.com ) \\ University of Kashmir https://orcid.org/0000-0001-5686-2476
}

\section{Research Article}

Keywords: Wild ungulates, helminth parasites, prevalence, EPG, mixed infection, Hirpora Wildlife Sanctuary

Posted Date: January 6th, 2022

DOI: https://doi.org/10.21203/rs.3.rs-1216666/v1

License: (c) (i) This work is licensed under a Creative Commons Attribution 4.0 International License. Read Full License 


\section{Abstract}

Parasitic infection represents an emerging threat to wild ungulates and a challenge to their management. Although a lot of work has been carried out on helminth parasitic infestation of domestic ungulates of Kashmir but the data pertaining to this aspect of wild ungulates has being ignored. The study on gastrointestinal helminth parasitic infestation of wild ungulates was carried out during post livestock grazing period (November to May) of 2018/2019 in Hirpora Wildlife sanctuary (HWLS) to fill the gap in the existing literature. During the study fresh faecal samples of musk deer Moschus sp.(n=44) and markhor Capra falconeri $(n=41)$ were collected and examined qualitatively and quantitatively for gastrointestinal helminth parasites. A total of seven helminth parasites were recorded which are arranged in the descending order of their overall prevalence as Haemonchus spp. (44.70\%),Nematodirus spp. (40\%), Trichuris spp. (37.64\%), Strongyloides spp. (34.11\%) Trichostrongylus spp. (28.23\%),Monieziaspp. (23.52\%) and Fasciola spp. (20\%). The mean EPG (eggs per gram) of different parasites showed a considerable variation in both the wild ungulates. The highest mean EPGwas that of Haemonchus spp. and the lowest mean EPG was that of Fasciola spp. in both hosts. A statistically significant difference was observed in the mean EPG of different parasites among two wild hosts $(\mathrm{t}=3.606, \mathrm{p}=0.01)$.

\section{Introduction}

Understanding gastrointestinal parasitic (GIT) diversity is of crucial importance for management of wild animals as these parasites pose a threat to the populations of different wild ungulates (Daszak et al., 2000) and play a vital role in survival of some major mammalian taxa (Lafferty and Gerber, 2002). Different parasites effect the growth and survival of various wild ungulates (Coop and Kyriazakis 1999). Different parasites effect the growth and survival of various wild ungulates (Ahmad 2020).In case of some wild ungulates helminth parasitic load is considered as one of the crucial factor, responsible for their extreme decline (Morgan et al. 2006). Helminth parasitic infection is responsible for mortality of hosts in protected areas on a major scale (Borghare et al. 2009). The effects of parasitism have become a serious concern for the conservation of various categories of ungulate species as it causes considerable population decline by causing mortality which may lead to extinction of some species (Ahmad 2020).

Gastrointestinal parasites are preferably present in duodenum, ileum, cecum and large intestines (Solusby 1982). These parasites have adapted themselves according to the feeding habits of the host, besides the continuous physiological changes related to feeding (Leonard 1987). These parasites drain the essential nutrients from the host rendering them weak and making them prone to other diseases (Loukopoulos et al.2007). The parasites of the gastrointestinal system pass the infectious propagules with the faecal matter which require the maturation period outside the body of host resulting in accumulation of the infectious agents in the habitat and increase their chances of transmission (Soulsby 1982).

The preliminary data on gastrointestinal parasitic infestation of hangul deer (Cervus hanglu hang/u) is available from Kashmir (Lone et al. 2016;Khurshid et al. 2021), but the baseline information on other wild ungulates is lacking. Keeping in view the global status of markhor Capra falconeri (Near Threatened, IUCN 2021) and musk deerMoschus spp. (Endangered, IUCN 2021), the present study was undertaken to examine the status of gastrointestinal helminth parasites of these two threatened mountain ungulates in the Hirpora 
Wildlife Sanctuary (HWLS) of Kashmir Himalaya for designing a future road map in parasitic disease monitoring and control in wildlife habitats.

\section{Materials And Methods}

\section{Study area}

The study was conducted in HWLS (33 $39^{\prime} 55^{\prime \prime} \mathrm{N}$ and $\left.73^{0} 39^{\prime} 40^{\prime \prime} \mathrm{E}\right)$ located at a distance of $70 \mathrm{~km}$ from Srinagar in Shopian district of Kashmir at an altitude of 2546mts (Ahmad et al. 2014) (Fig. 1). HWLS is surrounded by Lake Gumsar on north, Hirpora village on northeast, Rupri on east, Saransar on south and Pir Panjal pass on west. The steepness of mountain cliffs of HWLS varies, some of the peaks are very steep while as the others are moderately steep. The HWLS consists of different vegetation types like mixed coniferous forest, deciduous sub-alpine scrub forest and sub-alpine pastures. The sanctuary is known for Himalayan musk deer and Pir Panjal markhor (Ahmad et al. 2014). The sanctuary remains under the heavy grazing pressure of domestic live-stock belonging to local shepherds, migratory Gujars and Bukerwals from June to October (Bhat et al. 2019).

\section{Climate}

The climate of Kashmir valley is a typical warm temperate. The average temperature ranges from $30^{\circ} \mathrm{C}$ (maximum) and $20^{\circ} \mathrm{C}$ (minimum ) in June - July to $4^{\circ} \mathrm{C}$ (maximum) and $-9^{\circ} \mathrm{C}$ (minimum) in December January. The absolute humidity ranges from 50 - 80\% throughout the year and drops to about 55\% at night during the winter and $64 \%$ during the summer. The whole valley remains covered with snow in winter. On the basis of temperature and precipitation, four seasons are recognized in a year in Kashmir valley: winter (December to February), spring (March to May), summer (June to August) and autumn (September to November) (Dar et al. 2002).

Sample collection

During the period of investigation systematic surveys were carried in HWLS for the collection of samples. Fresh faecal pellets of markhor and musk deer were randomly collected on weekly basis from November to May of 2018/2019. In order to avoid contamination of samples, only that portion of the faecal sample was collected which was not in contact with the soil. Faecal pellets were placed in collection vials and zip lock bags which were carefully labelled with animal identification, species, date, and place of collection along with GPS coordinates. In-order to preserve the parasitic eggs/oocysts $4 \%$ formalin was added to collected samples. Preserved samples were transported to the Parasitology Research Laboratory, Department of Zoology, University of Kashmir where faecal samples were microscopically examined for helminth eggs and larvae using concentration methods by Zinc sulphate flotation, fecal sedimentation and Modified McMaster techniques (Soulsby 1982).Morphological characters like shape, size and color were used for identification (Soulsby 1982).

\section{Data analysis}


Percentages with their respective means \pm SD (standard deviation) and 95\% confidence intervals were employed to calculate the prevalence of helminth parasites. Eggs were estimated as number of eggs per gram of faeces with their respective median and percentile. Chi-square test was used to evaluate the significance in the EPG among different helminth species of two hosts. The data was analyzed using Statistical packages MINITAB software version 13.2 (Minitab 2002) and SPSS-17 for windows. Confidence level was held at $95 \%$ and $\mathrm{P}<0.05$ for significance.

\section{Results}

The results revealed multiple combinations of various helminth parasites in markhor and musk deer. Out of 44 samples of musk deer and 41 samples of markhor examined, 21(47.72\%) samples of musk deer and 19 (46.34\%) samples of markhor were positive for one or more than one species of GIT helminth parasites with an overall prevalence of $47.05 \%$. Nematodes were most prevalent in both the species of wild ruminants (Table.1).In musk deer the different helminth parasites recorded are arranged in the descending order of their prevalence as Haemonchus spp. (45.45\%), followed by Nematodirus spp. (40.90\%), Trichuris spp. (38.63\%), Strongyloides spp. (34.09\%), Trichostrongylus spp. 29.54\%),Monieziaspp.(25\%) and Fasciola spp.(20.45\%). The most prevalent parasite in markhor was Haemonchus spp. (43.90\%), followed by Nematodirusspp. (39.02\%), Trichuris spp. (36.58\%), Strongyloides spp. (34.14\%), Trichostrongylus spp. (26.82\%), Monieziaspp. (21.95\%) and Fasciola spp.(19.51\%)(Table.2). Haemonchuswas the most prevalent and Moniezia the least prevalent parasite in both hosts. A considerable variation was observed in the mean EPG among different parasites and between two hosts. (Table. 2).In case of musk deer the highest mean EPG (1605.14 \pm 416.50$)$ was that of Haemonchus spp. followed by Nematodirusspp. (1370.48 \pm 267.27$)$, Trichuris spp.

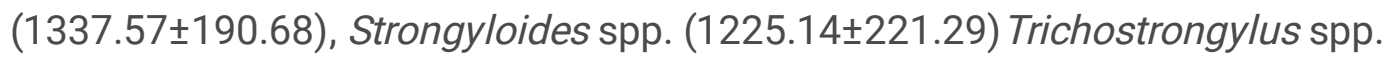

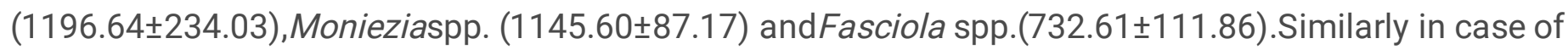
markhor the highest mean EPG recorded was that of Haemonchus spp.(1390.86 \pm 131.76$)$ followed

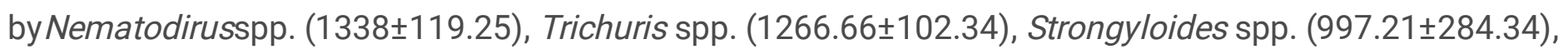

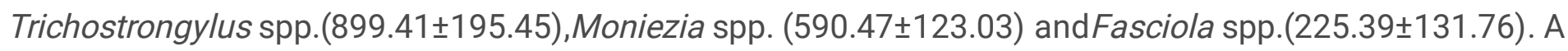
statistically significant difference was observed in the mean EPG of different parasites among two wild hosts $(t=3.606, p=0.01)$. Most of the positive samples of both the hosts were infected with the mixed infection of two or more than two species of parasites. Among21 positive samples of musk deer, 19 samples (90\%) (Table.4) were infected with mixed parasites and two with single parasite (one with Haemonchus spp. and one with Strongyloides spp. Similarly among 19 positive samples of markhor, mixed infection was reported in 16 samples (84.21\%) (Table.3) and single infection in three samples (two samples with Haemonchus spp. and one with Trichuris spp.)

\section{Discussion}

The literature on parasitic infestation of domestic ungulates is available from Kashmir (Bhat et al. 2019). The data pertaining to such aspect of wild ungulates is lacking from this region except some preliminary reports on hangul deer (Lone et al. 2016; Khurshid et al. 2021). Almost all the parasitic species reported in the two wild ungulate species are present in the domestic livestock which remain in the sanctuary from June to October (Bhat et al. 2019). The changing environmental conditions and utilization of natural habitats for live- 
stock grazing increases the risk of cross-transmission of parasites (Gottdenker et al. 2014). These parasites are reported by different workers in the captive wild animals from different areas (Fagiolini et al. 2010; Thawait et al. 2014). The prevalence reported in the study is in close agreement with other workers (Adeniyi et al. 2015; Lone et al. 2016; Khurshid et al. 2021). The prevalence of nematodes was more than cestodes and trematodes. The high prevalence of nematodes is because most of the nematodes reported in the study have direct life cycle and do not involve intermediate hosts for transmission which may account for their high transmission rate and prevalence (Soulsby, 1982). This is in close agreement with several studies (Mckenzie and Davidson, 1989; Pacon, 1994; Shibashi et al., 2003) who have also reported high prevalence of nematodes than trematodes and cestodes. The high prevalence of nematodes than trematodes and cestodes is in concordance with Santin et al., 2004 who has worked on several species of deer in Spain. Among the nematodes the most prevalent parasites recorded in these wild hosts was Haemonchus spp. which is in close approximation with the studies of several researchers of the world (Cook et al.,1979;Mason,1994;Naseimento et al.,2000).The low prevalence of cestodes and trematodes is because of limited availability of intermediate hosts which are important for their propagation (Soulsby, 1982). The low prevalence of cestodes in wild ungulates is in agreement with the studies of several workers(Vengust, 2003; Chroust and Chroustova ,2004)

The presence of Haemonchs spp., Moniezia spp. and Trichuris spp. in two wild ungulates of the study area is in concordance with Suzy et al. 1987 from the Davis Mountains of Texas. Haemonchus spp. and Trichostrongylus spp. recorded in the study have already been reported in some wild hosts (Rana et al. 2015; Bajwa et al. 2019). The high prevalence of Haemochus spp. and Nematodirus spp. revealed in the studyis because the infectious agents of these species have the tendency to with stand the harsh (dry and cold) environment for a long time (Poole 1956). Moniezia spp. reported in the study had already been reported in cervids of Pakistan (Rana et al. 2015), and wild sheep of Iran (Eslami et al. 1981).

The EPG in the present study is low as compared to the EPG recorded byLone et al. 2016 in hangul deer (Cervus elaphus hanglu) in Dachigam National Park Kashmir, India. This may be due to low group size, scattered population and less congregation of wild ungulates in HWLS. The EPG of different parasites showed considerable variation in two hosts and between different parasites. The highest egg count was that of Haemonchus spp. and lowest of Fasciola spp. This is because of the fact that production of eggs by the parasite depends on several factors which includes variation in the number of eggs produced by different parasites, individual host immunity and the severity of infection (Hudson et al., 1992: Zajac and Conboy, 2012). Some of the parasites like Haemonchus spp. are prolific and are capable of producing 5000 eggs per day while as others like Trichostrongylus produces only few hundreds (Stein et al., 2002). The mixed infection in most of the infected samples and the spectrum of helminths identified in the current study in which Haemonchus spp. was most prevalent is in agreement with previous studies conducted in different parts of the world (Ezenwa 2003; Waruira et al. 2005; Obanda et al. 2019).

The parasitic infestation decreases the response of the hosts towards secondary infection by causing immune suppression (Abee et al. 2012). The gastro-intestinal helminth fauna drains the essential nutrients rendering the animals weak which effects the reproductive potential and survival rate of hosts (Toft 1982; Panayotova- Pencheva 2013). The helminth parasites lower the body mass, reduce fecundity, and increase mortality among wild ungulates (Stein et al. 2002). The nematodes may significantly affect the general 
health of endangered animals by causing various morbidities and mortalities and play a vital role in population regulation of wild ungulates(Roche, 1988). Strongyloides spp. cause several ill effects like diarrhoea, anorexia, weight loss, anemia and dyspnea (Gupta et al.2011). Haemonchus spp. is known to cause intestinal ulceration leading to loss of blood, which makes the host weak and susceptible to other diseases besides causing significant morbidity and mortality (Davidson et al. 1980). The parasitic load can cause the death of hosts in severe cases which results in their population decline (Zhang et al.2008). Intestinal parasitosis is known to cause disease and death in some wild hosts as reported by several workers (Solórzano-García and Pérez-Ponce de León 2017), The present study needs further elaboration for understanding the impact of GIT helminth parasites on the diseases dynamics of threatened mountain ungulates in Kashmir.

\section{Conclusion}

The presence of gastrointestinal helminth parasites in markhor and musk deer with known ill impacts may threaten the survival of these two threatened mountain ungulates. This study has opened a vision for monitoring and managing of wildlife parasitic disease in livestock dominated protected areas, detailed investigation of the intensity of infection and evaluation of mode of transmission at length in future.

\section{Declarations}

\section{Acknowledgement}

Thanks are due to SERB-DST Govt. of India for providing financial assistance under the project number CRG/2019/002369.The financial assistance by the University of Kashmir under component 10 of RUSA 2.0 is duly acknowledged. Authors are thankful to the Head, Department of Zoology, University of Kashmir for providing laboratory and other facilities. Our sincere thanks goes to the Department of Wildlife Protection, Jammu and Kashmir for providing necessary permission. Our sincere thanks also go to Ifshan Deevan, Wildlife Warden Shopian, the team members of Wildlife Trust of India working in Jammu and Kashmir for their support and cooperation.

\section{Funding}

Study was financially supported by DST-SERB, Govt. of India New Delhi, India under the grant number CRG/2019/002369 and university of Kashmir under component 10 of RUSA 2.0.

\section{Conflict of interest statement}

The authors declare no competing interests. Equipment brands, chemicals, and other trade names are mentioned here solely for the convenience of the reader and imply no endorsement by the authors.

\section{Author contribution}

Rouf Ahmad Bhat: methodology, formal analysis, experimental work.

Hidayatullah Tak: investigation, formal analysis, visualization, writing-review, and editing. 
Bilal A. Bhat: conceptualization, methodology, writing-original draft preparation, and funding acquisition.

Riyaz Ahmad: sampling, methodology and analysis.

Ethics approval All procedures and methods used in this study regarding the use and care of animals were carried out in accordance with accepted international animal use and care guidelines.

\section{Statement of Animal Rights}

All animal sampling were carried out in open fields and followed international animal Ethical guidelines.

\section{References}

1. Abee C, Mansfield K, Tardif S, Morris T (2012) Nonhuman Primates in Biomedical Research: Diseases(. American College of Laboratory Animal Medicine Series, USA

2. Adeniyi IC, Morenikeji OA, Emikpe BO (2015) The prevalence of gastro-intestinal parasites of carnivores in university zoological gardens in South West Nigeria. J Vet Med Anim Health 7(4):135-139

3. Ahmad R, Dar SA, Suhail I, Zargar R, Charoo SA, Sofi MN, Mir FA, Bodhankar S, Bhattacharya T, Kaul R (2014) Recovering Markhor in Jammu and Kashmir, status, distribution, and habitat use. Wildlife Trust of India, Noida

4. Ahmad S (2020) Parasites of markhor, urial and chiltan wildgoat in Pakistan. Ann. Parasitol. 66(1):312.DOI: 101720/ap6601.232

5. Bajwa AA, Cuff JP, Imran M, Islam S, Mansha R, Ashraf K, Khan A, Rashid MI, Zahoor MY, Khan WA, Habib-ur-Rehman NA, Wenge O, Shehzad W (2019) Assessment of nematodes in Punjab urial (Ovis vignei punjabiensis) population in Kalabagh Game Reserve: development of a DNA barcode approach. Eur J Wildlife Res .65,63.https://doi.org/10.1007/s10344-019-1298-y

6. Bhat RA, Tak H, Bhat BA, Wani HM, Haq IUL, Ahmad R (2019) Livestock Helminth Infestation as A potential threat to wild Ungulates in Hirpora Wildlife sanctuary. J.Himalayan Ecol.Sustain.Dev.14,71-78

7. Borghare AT, Bagde VP, Jaulkar AD, Katre DD, Jamde PD, Maske DK, Bhangale GN (2009) Incidence of gastrointestinal helminthiasis of captive deers at Nagpur. Vet World 2(9):337-338

8. Cook TW, Ridgeway BT, Androeid R, Hodge J (1979) Gastrointestinal helminths in White tailed deer of luinois. J Wildl Dis 15(3):405-407

9. Coop RL .and Kyriazakis.Nutrition - parasite interaction.Vet.Parasitol. 84:187-204

10. Davidson WR, Crow CB (1980) Parasites, diseases and health status of sympatric populatons of white tailed deer and sika deer in Maryland and virgina. J wildl Dis 19:345-348

11. Daszak P, Cunningham AA, Hyatt AD (2000) Emerging infectious diseases of wildlife 328 - threats to biodiversity and human health. Science 287:443-449

12. Eslami A, Rahbari S, Meydani M (1981) Cestodesand trematodes of wild sheep, Ovis ammon orientalis,and goitered gazelle, Gazella subgutturosa, in Iran. Vet Parasitol 8:99-101

13. Ezenwa VO (2003) Habitat overlap and gastrointestinal parasitism in sympatric African bovids. J Parasitol 126(4):379-388 
14. Fagiolini M, Riccardo PL, Piero L, Paolo C, Riccardo M, Stefania P (2010) Gastrointestinal parasites in mammals of two Italian zoological gardens. J ZooWild Med 41(4):662-670

15. Gottdenker NL, Streicker DG, Faust CL, Carroll, C.R. (2014) Anthropogenic land use change and infectious diseases: a review of the evidence.Ecohealth, 11 pp. 619-632, 10.1007/s10393-014-0941-z

16. Gupta A, Dixit AK, Dixit P, Mahajan C, Shrivastava AB (2011) Incidence of gastrointestinal parasites in wild ruminants around Jabalpur. India J Threat Taxa 3(11):2226-2228

17. Hudson JP, Dobson PA, Newborn D (1992) Do parasite make prey vulnerable to predation? Red grouse and parasites.J. Anim Ecol 61(3):681-692

18. Islam S (2006) Parasites and parasitic diseases of wildlife. Proceedings of XVII National Congress of Veterinary Parasitology and National Symposium on "Strengths, Challenges and Opportunities". Vet. Parasitol. 43-52

19. Khurshid N, Tak H, Nazir R, Bhat KA, Manzoor M (2021) On the epidemiology of helminth parasites in Hangul Deer Cervus hanglu hanglu (Mammalia: Artiodactyla: Cervidae) of Dachigam National Park, India. J Threat Taxa 13(1):17517-17520

20. Leonard RJ (1987) : Physiology of gastrointestinal tract. 2nd ed. Raven press. $1780 \mathrm{p}$

21. Lone BA, Chishti MZ, Ahmad F, Tak H (2012) A survey of gastrointestinal helminth parasites of slaughtered sheep and goats in ganderbal. Kashmir Glob Vet 8:338-341

22. Lone BA, Chishti MZ, Ahmad F, Tak H, Bandh AS, Khan A (2016) A field survey on the status of gastrointestinal helminth parasites in hangul (Cervus elaphus hanglu) in Dachigam national park Kashmir. J Parasit Dis 40(30):750-755

23. Lafferty K, Gerber L (2002) Good medicine for conservation biology: the intersection of 399 epidemiology and conservation theory. Conserv Biol 16:593-604

24. Loukopoulos P, Komnenou A, Papadopoulos E, Psychas V (2007) Lethalozolaimus megatyphlon infection in a green iguana (Iguana iguana rhinolopa). J Zoo Wildl Med 38:131-134

25. Mason P (1994) Parasites of deer in New Zealand. N Z J Zool 21(1):39-47

26. Mckenzie ME, Davidson WR (1989) Helminth parasites of intermingling axis deer, wild swine and domestic cattle from this land of Molokai. Hawadii J Wildl Dis 25(2):252-257

27. IUCN (2021) The IUCN Red list of Threatened Species. Version 2021-2.https://www.iucnredlist.org

28. Morgan ER, Shaw SE, Brennan SF, De Waal TD, Jones BR, Mulc-ahy G (2006) Angiostrongylus vasorum: A real heart breakers. Trends Parasitol 21:49-51

29. Naseimento AAD, Bonuti MR, Mapell EB, Tebaldi JH, Arantes IG, Zettermann CD (2000) Nematodes Trichostrongylidae Cram, infections in deer (Mammals: Cervidae) from the States of Mato Grosso do Sul and São Paulo.Braz. J Vet Res Anim Sci 37(1/6):153-155

30. Obanda V, Maingi N, Muchemi G, Ng'ang'a CJ, Angelone S, Archie EA (2019) Infection dynamics of gastrointestinal helminths in sympatric non-human primates, livestock and wild ruminants in Kenya. PLoS ONE 14(6). DOI: 10.1371/journal.pone.0217929. e0217929

31. Pacon J (1994) Parasites of mouflons, stags and roe-deer from the Lower Silesia region. "Wiad Parazytologiczne" 40(3):279-292 
32. Panayotova-Pencheva MS (2013) Parasites in Captive animals: a review of studies in some European ZoosZool. Gart 82:6071. 10.1016/j.zoolgart.2013.04.005ArticlePDF(260KB

33. Poole JB (1956) Reaction to temperature by infective larvae of Nematodirus filicollis, Trichostrongylidae (Nematoda). Can J Comp Med 20:169-172

34. Rana MA, Jabeen F, Shabnam M, Ahmad I, Hassan MM (2015) Comparative study of endo-parasites in captive hog deer (Axis porcinus). Int J Biosci 6(1):162-170

35. Roche M, Layrisse M (1988) The nature and causes of hookworm anemia. Am J Trop Med 15(6):10311102

36. Santin DM, Alunda JM, Hoberg EP, Fuente CDL (2004) Abomasal parasites in wild sympatric cervids, red deer, Cervus elaphus and fallow deer, Dama dama, from three localities across central and western Spain: relationship to host density and park management. J Parasitol 90:1378-1386

37. Shibashi T, Shimamura A, Izumo A, Nogami S (2003) A survey of parasites in the feces of Sika deer, Cervus nippon, from Kanagawa, Saitama and Chiba prefectures, Japan. Jpn J Zoo Wildl Med 8(2):95-99

38. Stein A, Irvine RJ, Ropstand E, Halvorsen O, Langvatan R, Albon SD (2002b) The population dynamics of Ostertagia Gruheneri in reindeer:a modal for the seasonal and intensity dependent variation in nematode fecundity. Int J Parasitol 32(5):991-996

39. Suzy S, Stublefield DB, Pence and Robert J. W (1987) Visceral helminth communities of sympatric mule and white-tailed deer from the DavisMountains of Texas.J. wildl. Dis 23(1):113-120

40. Smith KF, Acevedo-Whitehouse K, Pedersen AB (2009) The role of infectious diseases in biological conservation. Anim Conserv 12:1-12

41. Soulsby EJL (1982) Textbook of veterinary clinical parasitology, vol I. Helminth Oxford Blackwell Scientific, London

42. Solórzano-García B, de Pérez-Ponce G (2017) Helminth parasites of howler and spider monkeys in Mexico: insights into molecular diagnostic methods and their importance for zoonotic diseases and host conservation. Int J Parasitol Parasites Wildl 6:76-84

43. Stein A, Irvine RJ, Ropstad E, Halvorsen O, Langvatn R, Albon SD (2002) The impact of gastrointestinal nematodes on wild reindeer: experimental and cross-sectional studies. J Anim Ecol 71:937-945

44. Thawait VK, Maiti SK, Dixit AA (2014) Prevalence of gastro-intestinal parasites in captive wild animals of Nandan Van Zoo, Raipur, Chhattisgarh. Vet. World. 7(7): 448-445.10

45. Toft JD (1982) The pathoparasitology of the alimentary tract and pancreas of nonhuman primates: a review. Vet Pathol 7:44-92. 10.1177/030098588201907s06

46. Vengust G (2003) Comparison of the parasitic fauna of fallow deer (Dama dama) from two enclosures in Slovenia. Slov Vet Zb 40(1):27-31

47. Waruiru RM, Otieno RO, Mutune MN (2005) Gastro-intestinal parasitic infections of sheep and goats in semi-arid areas of Machakos district. Kenya B A H PA 53(5):25-34

48. Zajac AM, Conboy GA (2012) “Veterinary Clinical Parasitology”. Jhon Wiley and Sons

49. Zhang JS, Daszak P, Huang HL, Yang GY, Kilpatrick AM, Zhang S (2008) Parasite threat to panda conservation. EcoHealth 5:6-9 


\section{Tables}

Table 1.Prevalence of nematodes, cestodes and trematodes in Markhor and Musk deer

\begin{tabular}{lccccc}
\hline Host & $\begin{array}{c}\text { Number } \\
\text { examined(n) }\end{array}$ & $\begin{array}{c}\text { No.of positive } \\
\text { samples }\end{array}$ & Nematodes(Prevalence) & $\begin{array}{c}\text { Cestodes } \\
\text { (Prevalence) }\end{array}$ & $\begin{array}{c}\text { Trematodes } \\
\text { (Prevalence) }\end{array}$ \\
\hline Musk deer & 44 & 21 & $21(47.72 \%)$ & $11(25 \%)$ & $9(20.45 \%)$ \\
Markhor & 41 & 19 & $18(43.90 \%)$ & $9(21.95 \%)$ & $8(19.51 \%)$ \\
Overall & $\mathbf{8 5}$ & $\mathbf{4 0}$ & $\mathbf{3 9 ( 6 3 . 4 2 \% )}$ & $\mathbf{2 0 ( 3 3 . 4 3 \% )}$ & $\mathbf{1 7 ( 3 0 . 2 9 \% )}$ \\
\hline
\end{tabular}

Table 2. Prevalence and mean EPG of different parasites in Markhor and Musk deer

\begin{tabular}{|c|c|c|c|c|c|}
\hline \multirow[t]{2}{*}{ Parasite } & \multicolumn{2}{|c|}{ Markhor $(n=41)$} & \multicolumn{3}{|c|}{ Musk deer $(n=44)$} \\
\hline & $\begin{array}{l}\text { Positive } \\
\text { samples } \\
\text { (Prevalence } \\
\% \text { ) }\end{array}$ & Mean EPG \pm S.D & $\begin{array}{l}\text { Positive } \\
\text { samples } \\
\text { (Prevalence } \\
\% \text { ) }\end{array}$ & Mean EPG \pm S.D & $\begin{array}{l}\text { Overall } \\
\text { prevalence }\end{array}$ \\
\hline Haemonchus spp. & $18(43.90 \%)$ & $1390.86 \pm 131.76$ & $20(45.45 \%)$ & $1605.14 \pm 416.50$ & $44.70 \%$ \\
\hline Nematodirus spp. & $16(39.02 \%)$ & $1338 \pm 119.25$ & $\begin{array}{l}18 \\
(40.90 \%)\end{array}$ & $1370.48 \pm 267.27$ & $40 \%$ \\
\hline Trichuris spp. & $15(36.58 \%)$ & $1266.66 \pm 102.34$ & $\begin{array}{l}17 \\
(38.63 \%)\end{array}$ & $1337.57 \pm 190.68$ & $37.64 \%$ \\
\hline Strongyloides spp. & $14(34.14 \%)$ & $997.21 \pm 284.34$ & 15(34.09) & $1225.14 \pm 221.29$ & $34.11 \%$ \\
\hline Trichostrongylus spp. & $11(26.82 \%)$ & $899.41 \pm 195.45$ & $13(29.54 \%)$ & $1196.64 \pm 234.03$ & $28.23 \%$ \\
\hline Moneizia spp. & 09(21.95) & $590.47 \pm 123.03$ & $11(25 \%)$ & $1145.60 \pm 87.17$ & $23.52 \%$ \\
\hline Fasciola spp. & $08(19.51 \%$ & $225.39 \pm 131.76$ & $09(20.45 \%)$ & $732.61 \pm 111.86$ & $20 \%$ \\
\hline
\end{tabular}

$t=3.606, p=0.01$

Table 3. Mixed infection of parasites in Markhor 


\section{Host}

Multiple parasites

\section{Markhor}

+ ve samples

(\%)

Haemonchus spp., Trichuris spp., Nematodirus spp., Fasciola spp., Trichostrongylus spp., $\quad$ 5(26.31\%) Strongyloides spp., Moniezia spp.,

Trichuris spp., Fasciola spp., Haemonchus spp.,Nematodirus spp., Trichostrongylus spp., $\quad 3(15.75 \%)$ Strongyloides spp

Trichuris spp., Moniezia spp., Haemonchus spp.,Strongyloides spp.,Nematodirus spp.

$3(15.75 \%)$

Trichostrongylus spp., Haemonchus spp., Trichuris spp.,Nematodirus spp., Strongyloides spp.

Trichostrongylus spp., Haemonchus spp.,Nematodirus spp., Moniezia spp.

Nematodirus spp., Haemonchus spp., Trichuris spp., Strongyloides spp.

$1(5.26 \%)$

Nematodirus spp. Haemonchus spp.

$1(5.26 \%)$

Total

16

$(84.21 \%)$

Table 4: Mixed infection of parasites in musk deer

Host

Multiple parasites

\section{Musk deer}

+ve samples

(\%)

$6(28.57 \%)$

$5(23.5)$

$4(19.04 \%)$

Trichuris spp., Moniezia spp., Haemonchus spp.,Strongyloides spp.,Nematodirus spp., Trichostrongylus spp.

Trichostrongylus spp., Haemonchus spp.,Nematodirus spp., Strongyloides spp., Fasciola 2(9.52\%) spp.

Fasciola spp., Trichuris spp., Haemonchus spp.,Strongyloides spp.,Nematodirus spp., Trichostrongylus spp.

Haemonchus spp., Trichuris spp., Strongyloides spp., Trichostrongylus spp.,Fasciola spp., 1(4.76\%) Moniezia spp

Total

$19(90 \%)$

\section{Figures}




\section{Figure 1}

Map showing the study area and the distribution of sampling points of two hosts. 